\title{
THE IMPORTANCE OF CONCEPTS AND MISCONCEPTS FOR DISCOVERING PRINCIPALS AND INFERENCE ACTIVATION IN THE SLOVAK LANGUAGE EDUCATION
}

\section{[VYZNAM KONCEPTOV A MISKONCEPTOV PRE OBJAVOVANIE ZÁKONITOSTI A AKTIVIZOVANIE INFERENCII VO VYUCOVANI SLOVENSKEHO JAZYKA]}

\section{Zuzana Kovacova}

doi: 10.18355/PG.2018.7.1.6

\begin{abstract}
The study points out the intellectual activity of pupils in acquiring knowledge about the grammatical system of the mother tongue and the acquisition of linguistic concepts. Methodologically, it is based on works on language and thinking. It emphasizes the function of concepts in thinking and the conceptualization process. The author draws on the knowledge of cognitive linguistics, emphasizing the relationship of language and thinking. The study identifies the role of conceptualization in education. Case studies demonstrate active learning of language terminology in teaching. The findings of the study identify the analogy in function of concepts and pre-concepts in the natural language and in the educational environment. The study contains pupils' success if the concept is emphasized.
\end{abstract}

\section{Key words}

inference, concept, prediction, term, semantics, meta language

\section{Anotácia}

Štúdia kladie do popredia rozumovú aktivitu žiaka pri nadobúdaní poznatkov o gramatickom systéme materinského jazyka a osvojovaní lingvistických pojmov. Metodologicky vychádza z prác o vzt’ahu jazyka a myslenia. Zdôraznuje funkciu konceptov v myslení a proces konceptualizácie. Autorka vychádza z poznatkov kognitívnej lingvistiky, akcentuje vztah jazyka a myslenia. Stúdia identifikuje úlohu konceptualizácie v edukácii. Prípadové štúdie demonštrujú aktívne poznávanie jazykovej terminológie vo vyučovaní. Závery štúdie identifikujú analógiu vo funkcii konceptov a prekonceptov $\mathrm{v}$ prirodzenom jazyku a v edukačnom prostredí. Štúdia obsahuje úspešnost' žiakov, ak sa akcentuje koncept pojmu.

\section{Kl'účové slová}

inferencie, koncept, prekoncepty, termín, sémantika, metajazyk

\section{Úvod}

Po tzv. kognitívnom obrate $\mathrm{v}$ psychológii a následne $\mathrm{v}$ humanitných vedách sa pozornost' vedcov sústred'uje na kognitívny aparát človeka. Ak dnes hovoríme o kognitívnej psychológii kognitívnej lingvistike, je opodstatnené 
hovorit' aj o kognitívnej didaktike. V prípade odborovej didaktiky slovenčiny to platí niekol'konásobne, ked'že v štruktúre kognitívnych vied je lingvistike venovaná vlastná pozícia. Inými slovami - jazyk je úzko spojený s myslením a vyučovanie jazyka znamená aj poznávanie aspoň časti nášho kognitívneho systému. Z vedecky akceptovaných teórií minulého storočia možno argumentovat' prácami J. Pjageta, Leva Vygotskeho či Luriju, v ktorých sú otázky spätosti jazyka a myslenia chápané v tesnej zviazanosti.

Kognitívne orientovaná didaktika slovenského/materinského jazyka by mala argumentovat' odkrývaním poznávacích procesov žiaka v konkrétnych fázach poznania a z nich dedukovat' vzdelávacie postupy i metódy. Didaktika materinského jazyka $\mathrm{v}$ intenciách konštruktivizmu vychádza $\mathrm{z}$ teórie prirodzeného jazyka a súčasne z prirodzených poznávacích procesov. Obidve vyššie uvedené požiadavky nie sú úplne a optimálne rešpektované v školskej praxi, resp. nie je im pripisovaný taký význam, aký im z ich samotnej podstaty prináleží. Pritom $\mathrm{v}$ ich intenciách ide o skutočné napĺn̆anie požiadavky (formulovanej aj v základných školských dokumentoch), ktorými sú: postupovat' od známeho k neznámemu, od jednotlivého k všeobecnému, od empírie $\mathrm{k}$ abstrakcii a pod.

Kognitívne orientovaná didaktika materinského jazyka znamená predovšetkým dôraz na kvalitu edukácie, pričom konečným meradlom je úspešnost' žiaka, ktorá sa navonok manifestuje $v$ jeho pohotových riešeniach a aplikácii poznatkov. Kognitívne orientovaná didaktika materinského jazyka si robí ambície stat' sa plnohodnotnou (a nie len aplikovanou) vedeckou disciplínou. K. Sebesta otázky intenčného vzdelávania vidí v širších súvislostiach aplikovanej lingvistiky (Šebesta, 2016, s. 121 - 130).

O identifikáciu konštruktivistickej paradigmy vo vyučovaní materinskému (českému) jazyku sa pokúsil S. Stepanik (2011, s. 73 - 78).

\section{Použité metódy}

Štúdia sa zaoberá otázkou efektívneho osvojovania vedomostí učiacim sa subjektom (žiakom) na hodinách slovenského jazyka, a to v zmysle osvojovania si základných pojmov, resp. v zmysle nadobúdania požadovaných performančných zručností v procese slohovej výchovy. Metodologicky sa opierame o teóriu živého slova N. F. Alefirenka (2009), ktorá interpretuje vznik a fungovanie asociačno-sémantickej siete vo vedomí človeka. Túto teóriu analyticky aplikujeme na edukačný proces jazykového vyučovania, ktoré v konečnom dôsledku smeruje k uvedomovanej reflexii jazykového systému slovenčiny ako materinského jazyka, ktorý z aspektu našich respondentov a ciel'ovej skupiny plní všetky funkcie prirodzeného jazyka. Rovnako berieme do úvahy vymedzenie tzv. elementárnych sémantických jednotiek v prácach A. Wierzbickej (2014). Naše predpoklady - hypotézy o efektívnom osvojovaní lingvistických pojmov manifestovaných $\mathrm{v}$ podobe jazykovedných termínov sme overovali vedukačnej praxi na konkrétnej skupine žiakov tak, že sme vytvorili kontrolnú skupinu, v ktorej sme nepostupovali $\mathrm{v}$ intenciách rešpektovania asociačno-sémantickej siete. Výsledky sme spracovali štatistickou metódou a znázornili grafom. Podobne by sme postupovali v prípade slohovej výchovy, kde by sme však kládli dôraz na prvotné získavanie predstavy o konkrétnom žánre vlastnou empíriou.

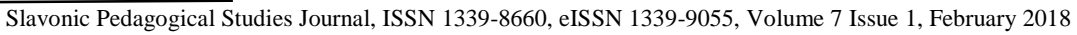


Rozdielnost' postupov je daná diferenciou v povahe samotného učiva, zatial' čo v prípade osvojovania lingvistických pojmov ide o intenčné poznávanie jazykového systému ako kódu, ktorý učiaci sa subjekt spontánne a prirodzene používa. (V prípade slohovej výchovy ide o nadobúdanie performančných dispozícií založených na poznaní jazykového kódu.) Osvojovanie si lingvistických pojmov a vnímanie ich vzájomných súvislostí akcentuje logické myslenie a vazyku ustálené gramatické pravidlá. Nadobúdanie performančných zručností si vyžaduje modelovanie komunikačnej situácie a rešpektovanie štandardných vlastností slohových postupov a slohových útvarov a dôraz je na hl'adaní analógií s percipovanými textami daného druhu, ktoré sa premietajú do individuálneho tvorivého aktu - do textotvorby. $\mathrm{Na}$ tomto mieste ešte treba pripomenút', že proces intenčného poznávania jazykového systému a jeho zákonitostí (čo je obsahom jazykovej zložky predmetu Slovenský jazyk a slohová výchova) je odlišný od jazykového vzdelávania zameraného na osvojovanie cudzieho jazyka. V prípade cudzích jazykov ide najmä o ,vrastanie do reči“ (parol), zatial’ čo v prípade materinského jazyka ide o intenčné poznávanie jazykového systému (lang).

Gardenfors (2000 in Benuskova, 2005, s. 250) navrhol novú teóriu reprezentácie, tzv. teóriu konceptuálnych priestorov, ktorú založil na geometrickom spôsobe reprezentácie. Ciel'om je vybudovat' most medzi modelmi neurónových sietí a modelmi mentálnych procesov, ktoré pracujú so symbolmi. Pridanie každej novej osi kvality v konceptuálnom priestore považuje za ekvivalentné vedeckému objavu. Toto poznanie o aktivite mozgu je relevantným pre tvrdenie, že v podmienkach vyučovania narábame s konceptmi a že do vzájomného dialógu v relevantnej odbornej oblasti vstupujú koncepty toho, kto nás k poznaniu vedie, t. j. učitel'a a toho, kto si osvojuje daný jav, t. j. žiaka. V prípade osvojovania si lingvistickej terminológie a spolu s ňou aj klúčového pravidla, je v hre na prvom mieste význam bežného (známeho) slova ako konceptu a novo poznávaný význam dovtedy neznámeho termínu, ako ciel'a intenčnej poznávacej aktivity. Samotný fakt, že z významu známeho slova - konceptu - dedukujeme význam nového termínu - konceptu, zabezpečí, že nový poznatok sa integruje do slovnej zásoby žiaka prirodzene a stáva sa organickou súčast'ou jeho mentálneho modelu.

V kontexte kognitivisticky orientovaných štúdií, ktorých autori hl'adajú odpovede na proces osvojovania si poznatkov žiackym subjektom treba spomenút' už etablované závery, že pokial' sú poznatky súčast'ou zmysluplnej kognitívnej štruktúry, sú lepšie pripravené na transfer a žiaci si tieto poznatky dlhšie zapamätajú (Manak, Janik, Svec, 2008). Konkrétne štruktúry detailnejšie charakterizoval Mares (1989, 2001), ked’ nadviazal na už staršiu teóriu štruktúrovania učiva (2001), v ktorej za kl’účové považuje to, že žiak nedostáva štruktúru hotovú, ale učí sa ju tvorit'. Tento poznatok je rozpracovaním názoru Markham, Mintzes a Jones (1994), ktorí otvorili otázku poznatku, poznania a zmyslu v mentálnom priestore žiaka. Za relevantné $\mathrm{v}$ tomto kontexte považujeme výskumy J. Duchovicovej a D. Gunisovej $(2015$, s. 148 - 171). Autorky sa zamerali na subjektívne vnímanie úspešnosti žiakmi (študentmi SŠ) v prípade štruktúrovania a neštruktúrovania učebného obsahu učitel'om. 
Štúdia sa sústred'uje na problematiku osvojovania relevantných pojmov žiakmi na 2. stupni ZŠ, a to v kvalite a rozsahu, ktorý zodpovedá označeniu zmysluplné učenie. Predmetom praktického výskumu je dosiahnutá miera úspešnosti v prípade rešpektovania princípov aktívneho osvojovania si nového pojmu v algoritme krokov: empíria žiaka s konkrétnym jazykovým javom sprevádzaná emocionálnym zážitkom - pozorovanie - riešenie parciálnych problémov/otázok cestou maximálnych a minimálnych diferencií $v$ adaptovaných a konceptualizovaných prostrediach sprirodzene účinkujúcim jazykovým javom - dedukovanie zákonitostí-abstrahovanie od menej relevantných vlastností - formulovanie výroku ako výsledku pozorovaní a dedukcií žiakmi.

Štúdia literárnou metódou prináša identifikáciu konceptov v l’udskom myslení, a to s dôrazom na vzt'ah konceptov a jazyka, resp. na vzt'ah jazyka a myslenia. Kladie si za ciel' dokázat', že samotnú edukačnú jednotku treba chápat' ako diskurzívny priestor, ktorý je porovnatel'ný s prirodzeným prostredím, v ktorom si diet’a/človek primárne osvojuje svet od útleho detstva, a to na základe výsekov vnímanej reality - konceptov, ktoré nie sú izolované od iných konceptov, ale medzi nimi sa vytvárajú vzt’ahy, ktoré sú vo vzt’ahoch konjunkcie, disjunkcie, koordinácie, implikácie či ekvivalencie. To znamená, že sú medzi nimi kvalitatívne rôzne logické vzt'ahy, ale najmä že sú navzájom viac či menej prepojené a spravidla hierarchizované.

Metódy výskumu: Pre potreby a ciele tejto štúdie sme aplikovali nasledovné metódy. Jadrom našej výskumnej aktivity bolo pozorovanie - konkrétne mikroanalýza vyučovacieho procesu v rámci edukačnej jednotky zameranej na osvojenie kl'účových pojmov v rozsahu učiva a štandardov druhého stupňa ZŠ. V odbornej literatúre sa zatial' nevyskytujú štúdie, ktoré by identifikovali edukačnú jednotku ako diskurzívny priestor v ktorom sa intenčne modeluje proces konceptualizácie (chápaný ako vnútorný a nanajvýš individuálny proces poznania $\mathrm{v}$ mentálnom priestore každého žiaka ako jedinečného a tvorivého indivídua). Získané výsledky sme štatisticky spracovali a znázornili dvomi grafmi. Predmetom pozorovaní boli edukačné jednotky $\mathrm{v}$ paralelných triedach, pričom $\mathrm{v}$ jednej skupine sa strategicky pracovalo s teóriou kognitívnej sémantiky (zameranej na význam nového pojmu), v druhej - kontrolnej skupine sa zachovalo lineárne radenie informácií a učebný obsah nebol štruktúrovaný s ohl'adom na poznávací algoritmus žiaka. V prvej - experimentálnej skupine sa kládol dôraz na zážitkovost' spojenú s primárnou empíriou, ako aj na deduktívne uvažovanie detí, ktoré spontánne prispievali do riešenia parciálnych problémov. V druhej skupine sa táto stránka neakcentovala, poznatok sa podával žiakom ako hotový, kl'účový význam bol pripisovaný len aplikovaniu pravidla a precvičovaniu.

\section{Konceptualizácia v l'udskom myslení - koncepty, prekoncepty a miskoncepty $v$ edukácii slovenského jazyka}

Čo nové o l'udskom myslení pribudlo v ostatných desat'ročiach minulého storočia a v 21. storočí. Popri dávnejšie známych myšlienkových operáciách, ktorými sú analýza, syntéza, abstrakcia a na nej založená kategorizácia, je tu už zjavne identifikovaný proces konceptualizácie, v ktorom sa reflektuje vzt’ah jazyka a myslenia. Pre človeka a jeho poznávanie či ozmyselňovanie 
sveta je od útleho detstva kl'účová konceptualizácia. Diet’a už v ranom detstve poznáva a reflektuje najjednoduchšie koncepty, ktorými sú najmä koncept rodiny, domova, farieb, emócií a pod. Utváranie konceptov ako zjednodušených schém na začiatku poznávania sveta pramení zo zmyslových vnemov. Koncepty sa postupne na seba vrstvia, kombinujú a najmä hierarchizujú. Budujú sa z rôznorodých prvkov od zmyslovej skúsenosti cez komunikačné či kultúrne stereotypy a ukladajú sa v našej mysli ako predstavy pretavené do obrazovej podoby. V konceptoch sa uchovávajú informácie, a to tak celého spoločenstva, ako aj jednotlivca.

\section{Konceptualizácia ako reflexia vzt’ahu jazyka a myslenia}

V prípade osvojovania si nových lingvistických termínov (čo v podstatnej miere tvorí obsah jazykovej zložky učiva v predmete slovenský jazyk a literatúra) ide $\mathrm{z}$ aspektu žiaka o porozumenie významom a následné funkčné používanie osvojených pojmov manifestovaných ako termíny. Termín v jazyku funguje podobne ako slovo, ked' sa jazykovému výrazu pripisuje sémantická reprezentácia. Otázka významov sa stáva kl'účovou, ak chceme identifikovat' vzt'ah jazyka a kognície, a teda aj nachádzat' odpovede na otázky súvisiace s pochopením termínov žiakmi. Problematika sa v kontexte lingvistického vysvetl'ovania významov v prirodzenom jazyku v prípade významov termínov zjednodušuje, pretože v prirodzenom jazyku môžu mat' slová niekol'ko významov - polysémia, ale v prípade termínov ide o jednovýznamové slová. J. Sefránek o význame z aspektu sémantiky hovorí: „Jedným z centrálnych problémov je problém uzemnenia symbolov (symbol grouding problem) - odkial' získavajú, kde nadobúdajú sémantické reprezentácie význam?“ (2005, s. 149). V podkapitole Kognitívna sémantika J. Sefranek o kognitívnej sémantike hovorí: „Súčasná kognitívna veda prijíma, že kognície (kognitívne systémy) využívajú (nejakú) reprezentáciu (prostredia/sveta) na orientáciu a konanie v prostredí. Obsahy mysle sú lokalizované $\mathrm{v}$ reprezentácii. Konštrukt reprezentácie je teda centrálny pre súčasný spôsob opisu a chápania kognície. Ciel'om kognitívnej sémantiky je vytvorit' takú koncepciu významu, ktorá začlení významy do reprezentácií do obsahu myslí“ (2005, s. 156).

Kognitivisti, napr. Gardenfors (2000) prichádza s teóriou konceptuálneho priestoru. Podl'a tohto autora konceptuálny priestor je teoretická konštrukcia. Ciel'om konceptuálneho priestoru je vysvetl'ovat' empiricky pozorovatel'né javy a udalosti. Konceptuálny priestor možno považovat' za kognitívnu štruktúru, lebo dovol'uje opísat' pozorovania z oblasti vnímania a poznania. J. Šefránek na margo teórie konceptuálneho priestoru hovorí: „Konceptuálny priestor je vhodnou reprezentáciou aj pre kognitívne systémy s predverbálnym (predjazykovým) správaním. Umožňuje to vidiet' súvislosti medzi kognitívnymi systémami rôznych typov a rešpektovat' biologickú bázu schopnosti rozlišovat', rozumiet', poznávat'. (...) jeho model je vhodný na reprezentáciu observačných (zmyslami vnímatel'ných) vlastností, tried a pod. Poskytuje aj riešenie problému uzemnenia symbolov.“

V teórii G. Lakoffa $(1987,2006)$ sa konceptuálny systém človeka uzemňuje v dvoch bodoch - v základnej rovine a v pojmoch, ktoré sú schematickými obrazmi zmyslovej a pojmovej skúsenosti (image-schematic concepts). 
V intenciách jeho teórie systém pojmov má základy, ale nemá primitívne pojmy. Jeden základný pojem možno charakterizovat' pomocou iných základných pojmov.

\section{Asociačno-sémantická siet' a analógia s osvojovaním si lingvistických pojmov (žiakom/učiacim sa subjektom) ako základných výrazov metajazyka lingvistiky}

Vd’aka konceptom sa v našej mysli vytvára asociačno-sémantická siet', ktorá sa nazýva aj asociačno-verbálna siet'. Konkrétne pojmy sa v nej na základe spracovania informácií a prenosom do štruktúr mozgu tzv. transmitermi usporadúvajú, organizujú a štruktúrujú. Používanie pojmov v konkrétnej relevantnej situácii nastupuje $\mathrm{v}$ zlomku sekundy na základe asociácie. $\mathrm{V}$ prípade, že pojem nebol v našej mysli konceptualizovaný, sa do asociačnosémantickej siete neimplementoval, nevznikli prepojenia medzi inými známymi pojmami a slovami, preto sa očakávaná asociácia nespustí, čo sa navonok prejaví tak, že sa nevieme na konkrétny pojem či význam rozpamätat'. Relevantná čast' konceptu sa teda aktualizuje v prípade, ak sa potrebujeme na niečo rozpamätat', pričom náš mozog aktivizuje všetky d’alšie nejako spolupracujúce či súvisiace koncepty, a to v podobe asociácií. Medzi nástupom asociácií a spôsobom, akým sa daný poznatok konceptualizoval, je priama súvislost'.

Asociácie sú tým, dosial' nie celkom úplne prebádaným fenoménom, ktorý je zodpovedný aj za schopnost' intuície, ked’ naše podvedomie spúšt’a v mozgu biliardy možností a permutácií, aby sme vd’aka jeho výkonu dospeli až $\mathrm{k}$ matematicky presnému odhadu pravdepodobnosti, čo sa považuje za úspešné riešenie problému. Potenciál l'udského mozgu je prirovnávaný $\mathrm{k}$ tkáčskemu stavu, na ktorom milióny člnkov tkajú zložitý, ale zmysluplný vzor, ktorý však nefunguje sám osebe, ale rýchlo sa mení v harmóniu menších vzorov.

V intenciách vyššie spomenutej teórie G. Lakoffa $(1987,2006)$ vel’a základných pojmov a kategórií má oporu v telesnej skúsenosti. Niektoré sa identifikujú ako analógia so schematickým obrazom nádoby (container) a nominácie súvisia $\mathrm{s}$ obsahom alebo povrchom nádoby, môžu súvisiet' so stenami nádoby ako hranicou medzi vnútorným a vonkajším prostredím, môžu súvisiet' s povrchom či dnom nádoby, ale aj s deštrukciou nádoby. Podobne je funkčný schematický obraz spojenia/pripútania (link) či schéma radiálneho pripojenia. Schémy sa môžu navzájom kombinovat' či vrstvit', môžu byt' vo vzt'ahu centrum - periféria, celok - čast', zdroj - cesta - ciel'. Tieto schémy sú ako predpojmové štruktúry spájané s elementárnou pohybovou skúsenostou (kinesthetic image schems) a vrámci nich ako $\mathrm{v}$ rámci modelov sa formuje naša l’udská kategoriálna výbava.

Ak $\mathrm{v}$ istej etape jazykovej edukácie reflektujúcej náš vlastný gramatický systém prikročíme $\mathrm{k}$ osvojovaniu sústavy lingvistických pojmov manifestovaných ako lingvistické termíny, pojmy budú vstupovat' do podobných schematických vztahov, pretože ony samy sú vo svojej podstate konceptami, resp. uchovávatel'mi konceptov. Cesta $\mathrm{k}$ ich osvojovaniu je teda $\mathrm{v}$ procese konceptualizácie, pričom tento proces musí prebiehat' v relevantnom mentálnom priestore a vyžaduje si reálny časový interval.

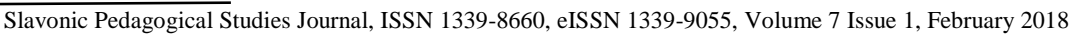


V súvislosti s konceptualizáciou pojmov treba zdôraznit', že autorská dvojica A. N. Alefirenko - N. B. Korina nazerajú na slovo ako na koncept (2011, s. 39 - 45). Zrod nových významov predstavil N. F. Alefirenko vo svojej teórii živého slova (2009) a v kontexte tejto teórie analogicky vnímame termín v našom prípade lingvistický termín nielen ako označenie pojmu, ale aj ako koncept, ktorý má svojho ,predchocu“ v inom - v hierarchii konceptov nižšie postavenom koncepte, a to alebo inom jednoduchšom a sémanticky priezračnom termíne, alebo v bežnom slove, ktoré je tiež uchovávatel'om konceptu. Uvedená teória korešponduje s teóriou sémantických univerzálií A. Wierzbickej (2014, s. 31 - 33), ktorá ju formulovala v kontexte utvárania prvých významov a pojmov v ontológii detskej reči. A. Wierzbicka vychádza z perspektívy pochopit' sémantické univerzálie na základe dedukovania elementárnych významov špecifickej (nejako - najmä formálne či sémanticky) súvisiacej skupiny slov.

\section{Architektúra edukačnej jednotky ako iniciácia konceptualizácie a následného vytvárania pojmov - dedukcia a osvojovanie metajazyka založeného na lingvistickej terminológii}

\section{Konceptualizácia $v$ intenciách architektúry edukačného prostredia}

V kognitívne orientovanej didaktike slovenčiny hl'adáme analógie s dvomi dominantnými východiskami, ktorými sú teória prirodzeného jazyka a kognitívna psychológia, ktorá sa orientuje na podstatu kognitívnych poznávacích procesov človeka. Ak si teda človek na úsvite dejín l’udstva a analogicky aj na úsvite etablovania reči či prirodzeného jazyka ako systému pravidiel a významov - vytváral prvé významy a pojmy tak, že ich konceptualizoval, je logické uvažovat' o vytváraní či modelovaní konceptov vo vyučovacom procese. Každá edukačná jednotka, ktorá je zameraná na osvojenie si nového pojmu, by mala implicitne obsahovat', resp. svojou vlastnou podstatou predstavovat' invariant konceptu, ktorý bude každý žiacky subjekt prežívat' $v$ istej miere jedinečne, no so spoločným kl'účovým jadrom. Súčast'ou budovania konceptu je zmyslové vnímanie, východiskový bod v konkrétnej skúsenosti so živým jazykom ako s artefaktom, z ktorého sa bude nový pojem dedukovat'.

Pod konceptualizáciou nových pojmov rozumieme proces poznávania nových významov, ktorý má obligatórne súčasti. Tie vyplývajú z biologickej podstaty prenosu primárnych zmyslových vnemov (plynúcich z empírie a aktu observácie konkrétneho jazykového javu) ako nových a špecifických informácií do mozgovej kôry, z biochemickej premeny krátkodobej informácie na trvalý poznatok, zo simultánneho prežívania emócie a osobitne aj emócie plynúcej z presvedčenia, že žiak novú súvislost' objavil sám, čo by sme vcelku mohli subsumovat' pod výraz rešpektovat' biologickú bázu schopnosti rozlišovat', rozumiet', poznávat'.

Zdôrazňujeme požiadavku prežívania emócie založenej na vnímaní niečoho netradičného, premyslenú prípravu - režírovanie systému otázok a odpovedí, ktoré reflektujú dyadické myslenie a početné čiastkové analýzy a syntézy, čiastkové dedukcie až po konečnú dedukciu vedúcu k spoluobjaveniu nového 
javu - pojmu, primárny či opakovaný pocit novosti a z toho prameniaci pocit úspechu.

Každý nový význam osvojený subjektom a uložený v jeho pamäti je konceptuálnou štruktúrou $\mathrm{v}$ konceptuálnych priestoroch. V edukačnom procese je východiskom pre konceptuálnu štruktúru implementovanú do mentálneho modelu subjektu (učitel'om, učebnicou, vzdelávacím programom) interpretované učivo - téma, ktorej jadrom je (v prípade jazykového vyučovania) spravidla nový jav, zákonitost', ktorá je pomenovaná novým termínom prislúchajúcim novému pojmu.

Na individuálne prežívaný procesom konceptualizácie priamoúmerne pôsobí edukačná jednotka, resp. jej architektonický projekt, ktorý v mene úspešnosti má byt' implicitne naplnený spoluobjavovaním, ktoré môžeme zjednodušene komprimovat' do algoritmu krokov: učitel' systematicky radí indície a žiak sa cez čiastkové dedukcie posúva ku konečnej dedukcii. Čiastkové dedukcie sú založené na analyticko-syntetických operáciách.

Konceptuálnym priestorom je mysel' žiaka a vzniká práve v tvorivom v dialógu s mysl'ou učitel'a. Učitel' vedie žiaka po ceste k objaveniu nového javu, pričom cesta má úskalia a zákruty a každá z nich je prekážkou, ktorá vznikla ako istý rozpor so zadanou indíciou, musí teda nasledovat' d'alšia indícia, ktorá je vzhl’adom k predchádzajúcej vo vzt’ahu špecifikácie.

Konceptuálne štruktúry ako významy a konceptuálne priestory vstupujú do vzájomnej komunikácie a navzájom sa prispôsobujú. Ak nie, účastníci komunikačného aktu v špecifickej komunikácii, akou je pedagogická komunikácia (subjekt U a subjekt Ž) si nebudú rozumiet', nebudú môct' spolupracovat', t. j. ich komunikácia je diskrepantná, a teda nefunkčná, pretože nedošlo k žiadnej relevantnej výmene informácie, resp. k vzájomnému obohateniu sa na základe komunikácie.

Čo je kl'účové pre interakciu v procese spoluobjavovania nových pojmov (žiaka a učitel'a) v škole projektovanej a modelovanej situácie vedúcej k osvojeniu pojmu v zmysle individuálnej konceptualizácie patriacej do mentálneho priestoru žiaka. Každá dedukcia musí mat’ nejaké - v danej komunite (žiacky kolektív) už známe - východisko. To môže byt' všeobecného charakteru, t. j. môže to byt' bezpríznakové slovo bežného významu, ale môže to byt' aj špecifický pojem reprezentovaný termínom. So stúpajúcim ročníkom a náročnost'ou učiva je čoraz viac pravdepodobné špecifické východisko, a to v zmysle/podobe už osvojenej vedomosti, už známeho pojmu (jeho významu). Toto prepojenie chápeme ako jav inferencie.

\section{Funkčné využitie prekonceptov a miskonceptov pri osvojovaní si lingvistických pojmov}

Pri intenčnom poznávaní sa analogicky opakuje stratégia nášho mozgu, a to zo známeho, ktoré nejakým spôsobom súvisí so zadanou úlohou (napr. s dedukciou konečného či čiastkového pojmu/významu) dedukovat'/vyvodit' nové, t. j. neznámy pojem. Na základe všeobecných i špecifických vedomostí si vytvárame tzv. prekoncepty, ktoré účinkujú ako predpoklady či ucelené hypotézy, ktoré, ak sme uvažovali správne, sa následne potvrdia. Takým najjednoduchším príkladom je princíp indexovosti v systéme znakov. Napr. 
vnímanie dymu u človeka indikuje predpoklad hraničiaci s istotou existencie ohňa.

Vplyvom nedostatočnej databázy východiskových premís nevznikajú logicky využitel'né komplexné predpoklady - prekoncepty, v dôsledku čoho učitel' nemôže novú vedomost' vyvodit' zo staršej a známejšej, teda nemá v oporu $\mathrm{v}$ premostení, akým je $\mathrm{k}$ inferencia. Vtedy žiak formuluje výpovede ako hypotézy, ktoré vychádzajú z jeho naivnej, teda neodbornej či výrazne zjednodušenej interpretácie daného javu. Mylné - chybné prekoncepty detské či tzv. naivné poňatia dostali pomenovanie miskoncepty. Pre učitel'a sú $\mathrm{v}$ istom zmysle prekážkou na ceste $\mathrm{k}$ efektívnej konceptualizácii, ale súčasne sú výzvou, ako typologicky analogickou cestou, ktorou vznikli (no opačným smerom až po kl'účový bod, v ktorom pôvodne nastal chybný krok), priviest' žiakov k správnemu východisku (tým sa ozrejmuje situácia celému kolektívu triedy) a nastolí sa rovnováha medzi správnym východiskom a očakávanou čiastkovou dedukciou po početných čiastkových analytickosyntetických operáciách. Pred konečnou dedukciou, z ktorej vzíde nový pojem - termín, musí dôjst' $\mathrm{k}$ abstrahovaniu kritéria a relevantnej kategorizácii.

Prípadová štúdia A pre dôkaz uplatnenia algoritmu vedúceho ku konceptualizácii spoluobjavovaním (žiaka a učitel'a vo vzájomnej interakcii): Krok 1: Je zameraný na observačnú aktivitu a zmyslové vnímanie: Použijeme text - ako príklad jazykovej praxe - s výskytom relevantného jazykového javu:

Východiskový text: Evička a jej mama majú sviatok v ten istý deň Evička oslavuje narodeniny a mamka meniny. Otec sa rozhodol, že na oslavu tohto dvojitého rodinného sviatku ich pozve do reštaurácie. Úlohou Evky bolo, aby zostavila pre všetkých pozvaných hostí slávnostné menu. Plánovali pozvat'aj starých rodičov. Evka vedela, že stará mama nepije čiernu kávu a starý otec nemá rád sladkosti. Dostala do ruky jedálny lístok a dala sa do práce. Pomaly čitala: hovädzi vývar, zeleninové rizoto, vyprážaný rezeñ, opekané zemiaky, zemiakové lokše, bravčová pečeň, dusená ryža, grilované rebierko, kuracie prsia .... pochopila, že to nebude l'ahká úloha. Otočila stranu a pozrela si nápojový lístok: čierna káva, írska káva, l'adová káva, l'adový čaj, zelený čaj. O kúsok d'alej: dezertné vína, šumivé vína, prírodný ovocný mušt ... Zatvorila jedálny lístok z ned'alekej reštaurácie a rozhodla sa, že jej otecko bude musiet' pomôct'.

Krok 2: Hlasné čítanie textu smerujúce $\mathrm{k}$ elementárnemu porozumeniu obsahu.

Krok 3: Otázka smerujúca k identifikácii najtypickejších nominácií v jazyku: V texte sa nachádzajú pomenovania osôb, vecí, rodinných príslušníkov, napíšte aspoň 5 (Riešenie: mama, sviatok, narodeniny, hostia, den̆. Doplňujúca otázka: Kol'kými slovami sme ich pomenovali? Odpoved': Jedným slovom.

Krok 4: Sú v texte pomenované veci či osoby, na pomenovanie ktorých potrebujeme najmenej dve slová? (Riešenie - odpoved': starí rodičia, jedálny lístok, hovädzi vývar, zeleninové rizoto, vyprážaný rezeň, opekané zemiaky, zemiakové lokše). Otázka: Kol'ko vecí pomenovávajú? Odpoved': Jednu. 
Kol'ko slov sme použili na pomenovanie jednej veci? Odpoved': Dve, resp. viac slov.

Krok 5: Rekapitulácia po primárnej diferencii: V jednej skupine máme ... (pokračujú žiaci na základe zaznamenanej rovnorodej skupiny, v tomto prípade dvoch rovnorodých skupín slov, z ktorých každá dostala pomenovanie - jednoslovné vs. dvojslovné/viacslovné). Odpoved': Ide o jednoslovné pomenovania, $v$ druhej skupine ide o viacslovné pomenovania.

Krok 6: Rozhodujúca otázka pre abstrahovanie: Kol'ko vecí pomenovávajú spojenia ako jedálny lístok, zemiakové lokše? Riešenie: Jednu. Pomocná otázka: Môžeme ich od seba oddelit? Riešenie: Nemôžeme.

Krok 7: Identifikácia dôsledku predchádzajúceho čiastkového záveru plynúceho z textom sprostredkovanej empírie, pričom dôsledok sa pomenuje výrazom bežného charakteru, ktorý je sémanticky najbližšie k očakávanému ciel'ovému pojmu: Odpoved', resp. čiastkový záver anticipujú žiaci: Stoja stále pri sebe, pretože sa spojili/združili pri pomenovávaní.

Krok 8: Záver: Obsahom konečného výroku ( $v$ ňom sa reflektuje predchádzajúce empíria a reflexia ret’azenia epizód poznávania a uvažovania) je nový pojem manifestovaný ako termín: Takéto pomenovanie dostalo názov: združené pomenovanie.

Prípadová štúdia B: Známym miskonceptom u detí je predpoklad, že dvojčlenná veta má vždy dve slová. K tomuto predpokladu dospeli v zmysle identity slova dvojčlenná a obsahom čísla 2 . A rovnaká operácia je zodpovedná za predpoklad, že jednočlenná veta obsahuje 1 slovo.

Krok 1: V invokácii známeho poznatku si pripomenieme, že v prípade dvojčlennej vety vieme, kto vykonáva dej (je nositel'om deja, stavu, vlastnosti).

Krok 2: Ako východisko použijeme vetu: Neodpovedal. Otázka založená na elementárnom porozumení významu: Vieme kto? Odpoved’: On. Pomocné otázky, smerujúce k identifikácii hlavných vetných členov: Čo sa dialo? Odpoved': Neodpovedal. Čiastkový záver: Vyjadrený vetný člen je prísudok. Otázka: Vieme, kto dej vykonáva? Odpoved': On. Z odpovede, ktorá má logický argument $\mathrm{v}$ gramatických kategóriách prísudkového slovesa, dedukujeme d'alší hlavný člen vety (explicitne nevyjadrený, resp. anticipovaný gramatickými kategóriami prísudkového slovesa), ktorým je podmet.

Krok 3: Otázka smeruje k rekapitulácii práve realizovanej operácie založenej na empírii: Kol'ko členov vety sme našli? Odpoved': Dva.

Krok 4: Nasleduje otázka, ktorou spoločne so žiakmi vstupujeme do diskusie so vstupným predpokladom - miskonceptom ako naivnou/zjednodušenou reprezentáciou problému. Aká je teda veta Neodpovedal? (ked’že sme identifikovali dva vetné členy, a to aj napriek tomu, že celú vetu tvorí jedno slovo) Odpoved': Dvojčlenná.

Krok 5: Formulácia výroku (žiakmi) na základe predchádzajúcej empírie: Dvojčlenná veta má vyjadrené dva vetné členy, a to podmet a prísudok. Mô̆e ju tvorit' len jedno slovo.

Prípadová štúdia C: Je zameraná na identifikáciu jednočlennej vety, t. j. na abstrahovanie od vety dvojčlennej v súvislosti s vyššie uvedeným príkladom. 
Krok 1: Je zameraný na observačnú aktivitu a zmyslové vnímanie: Použijeme vetu: Vo vysokom snehu sa išlo t’ažko.

Krok 2: Otázka založená na elementárnom porozumení významu vety: Čo sa dialo? Odpoved': Išlo sa.

Vieme komu sa išlo t'ažko? Odpoved': Jemu. Doplňujúca otázka: Aký vetný člen to je, ked' ho zasahuje slovesný dej? Pomocná otázka: Akým slovným druhom a vakom páde je vyjadrený? Odpoved': Zámenom v dative. (čo nezodpovedá kritériám vyjadrenia podmetu). Odpoved' na otázku identifikovania vetného člena: Predmet. Otázka: Ako sa išlo v snehu? Odpoved': Ťažko. Doplňujúca otázka: Aký vetný člen to je, ked'vyjadruje okolnost' deja? Odpoved': Príslovkové určenie. Otázka: Kde sa kráčalo t'ažko? Odpoved': V snehu (príslovkové určenie). Otázka: Aký bol sneh? Odpoved': Vysoký. (prívlastok).

Krok 4: Nasleduje otázka, ktorou spoločne so žiakmi vstupujeme do diskusie so vstupným predpokladom - miskonceptom ako naivnou/zjednodušenou reprezentáciou problému, a to, že jednočlenná veta má len jeden vetný člen. Kol'ko členov sme identifikovali vo vete Vo vysokom snehu sa išlo t’ažko? Odpoved': Šest'. Odpoved' vyvrátila predpoklad, že jednočlenná veta má len jeden vetný člen.

Krok 5: Nasleduje otázka, ktorou indikujeme dedukciu pojmu jednočlenná: Ktorý člen je kl'účový pre to, čo sa odohráva? (Resp. Čo sa dialo vo vete?) Odpoved': Išlo sa. Nedokončený výrok (na doplnenie žiakmi): Ked’že z vety, resp. z tvaru slovesa išlo sa nevieme dedukovat', kto je pôvodca deja, ide o: Odpoved': (...) jednočlennú vetu.

Krok 6: Formulácia výroku (žiakmi za pomoci učitel’a) na základe predchádzajúcej empírie: Tvar slovesa išlo sa neumožn̆uje anticipovat' ani kategóriu rodu, ani kategóriu čísla. (Ide o reflexívny tvar slovesa v tvare všeobecného neutra.) Do (obligatórnej/záväznej) požiadavky gramatickej stavby dvojčlennej vety nám chýba pôvodca deja.

$\mathrm{V}$ nami uvedených prípadoch ide o využitie miskonceptu, ktorý je u žiakov značne rozšírený, pretože ich k nemu vedie sémantika označenia jednočlenná veta, resp. dvojčlenná veta. Aj mylný predpoklad je výrazom žiackeho uvažovania a ponúka začiatok diskusie o probléme, ktorá vyústi do korigovaného, resp. revidovaného názoru, teda miskoncept sa premení na korektný koncept pojmu. Kl'účovým je pritom fakt, že revíziu robí žiak sám, jeho uvažovanie je vystavené kontrole a nasmerované vždy k správnym dedukciám. Žiak je rozumovo aktívny, je vedený k argumentácii a v konečnom dôsledku aj k sformulovaniu výroku, ktorý je pravdivý, teda do d'alšieho uvažovania či aplikovania poznatku relevantný oporný bod. Konečná dedukcia výroku je výrazom poznania učiaceho sa subjektu, čo sa d'alej manifestuje ako individuálny poznatok. Pamät' žiaka získala od poznávacích štruktúr dostatok impulzov, aby vedomost' uložila. Pod spomenutými impulzmi rozumieme: 1. Učiaci sa subjekt vychádza z jazykovej reality, ktorú predstavuje vždy text ako funkčné využitie jazyka. 2. Učiaci sa subjekt robí rozhodnutia na osi Áno - Nie / Správne - Nesprávne. 3. Učiaci sa subjekt sa v uvažovaní posúva sám, čím vynakladá energiu. 4. Učiaci sa subjekt po viacerých čiastkových záveroch formuluje konečný záver v podobe správneho výroku. 5. Učiaci sa subjekt bol k celej aktivite 
motivovaný presvedčením plynúcim z poznania reálneho problému ukotveného v jazykovej realite. 5. Učiaci sa subjekt, resp. jeho pamät' je iniciovaná presvedčením, že k poznaniu dospel sám. 6. Učiaci sa subjekt jeho hypothalamus - „lobuje“ v pamät’ových štruktúrach za uloženie poznatku, pretože je iniciovaný tiež prežívaním emócie, a to prvýkrát plynúcej z recepcie textu a jeho implicitnej hodnoty; druhýkrát z prežívania emócie úspechu pri riešení úlohy a konečného problému.

$\mathrm{Na}$ začiatku tu uvedených miskonceptov súvisiacich s kl'účovými východiskami v oblasti syntaktického učiva stojí zúžený pohl'ad žiaka na problém, ktorý vznikol $\mathrm{v}$ dôsledku absencie konceptualizácie pojmu stojaceho $\mathrm{v}$ hierarchii pojmov nižšie. Preto žiak vychádza z konceptu významu primárneho pomenovania typu: jeden člen - jedno slovo. Na konci procesu je akceptovanie (v podobe aktívneho rozumového prijatia) nových determinantov pri identifikácii elementárnej syntaktickej opozície jednočlenná a dvojčlenná veta. Zúžený pohl'ad na celý problém žiakom (vedúci k chybnému predpokladu, a teda aj d'alšiemu kumulovaniu nesprávnych rozhodnutí pri riešení relevantných úloh) indikujú poznanie, že asimilácia a akomodácia ( $\mathrm{v}$ tomto prípade ako mentálne javy u žiakov) sú základné procesy pri aktívnej konštrukcii poznania.

\section{Porovnanie prístupu transmisívneho a konštruktivisticky orientovaného učitel'a slovenského jazyka}

Vyššie opísané prípadové štúdie a takto poňaté vyučovanie považujeme za konštruktivisticky poňaté riadenie žiakovej učebnej činnosti. Na porovnanie rozdielnych prístupov s reflexiou vyššie uvedeného prinášame porovnanie postupov, ktoré je súčasne argumentáciou v prospech rozumovej či mentálnej aktivity žiaka ako učiaceho sa subjektu a je cestou, prejdením ktorej si subjekt konštruuje poznatok vo svojom konceptuálnom priestore sám:

Transmisivno-inštruktívny učitel’ slovenčiny žiakovi vysvetl'uje, aké slová, resp. vety v jazyku máme.

Konštruktivista - učitel' slovenčiny prinesie ,živý jazyk, ktorý sa dá ohmatat'. “

Transmisivno-inštruktívny učitel’ slovenčiny oznámi žiakom pravidlo v podobe poučky, resp. zákona.

Konštruktivista - učitel’ slovenčiny vychádza z predstavy žiaka ako malého vedca, ktorý objavuje vedecké pravdy vlastnou bádatel'skou aktivitou.

Transmisivno-inštruktívny učitel' slovenčiny vydáva inštrukcie pri riešení cvičení a úloh odvolávajúc sa na poučku či pravidlo.

Konštruktivista - učitel' slovenčiny v konfrontácii s okolitým svetom, resp. jazykovou realitou utvára a kreuje poznanie žiakov na základe ich vlastných skúseností, ktoré predtým sám „vyvolal“, resp. ich narežíroval v koncepte časti edukačnej jednotky

Transmisivno-inštruktívny učitel’ slovenčiny sa opiera o „diktát“" pravidiel.

Konštruktivista - učitel' slovenčiny vyhl'adáva a uprednostňuje individuálne skúsenosti žiaka a jeho individuálnu konfrontáciu so svetom. Teda využíva aj mylné či zjednodušené predstavy žiaka o danom jave. 
Transmisivno-inštruktívny učitel' slovenčiny je mentorom a „dohliada“ na správne riešenia úloh bez toho, aby hlbšie analyzoval problém. Zostáva pri mechanickom opravovaní chyby.

Konštruktivista - učitel' slovenčiny prestáva byt' mentorom, ale stáva sa facilitátorom. Nachádza miesto, v ktorom sa žiak opakovane mýli a robí s ním krátke vstupy do relevantného algoritmu uvažovania, aby došlo k rekognícii a následnej korekcii nesprávnej úvahy žiakom.

Transmisivno-inštruktívny učitel' slovenčiny narába so žiakom ako s pasívnym recipientom, ako s objektom svojich inštrukcií a výrokov.

Konštruktivista - učitel' slovenčiny chápe žiaka ako partnera v odborne orientovanej diskusii, ako aktívnu zložku edukačného procesu.

Zatial' čo transmisivno-inštruktívny učitel' sa pohybuje v intenciách učebnice a pomocných kníh, konštruktivista pripravuje a didakticky upravuje pramene poznania. Konštruktivista - učitel' slovenčiny chápe text ako výraz jazykovej praxe. Sám vytvára adaptované texty, aby v nich žiak mohol identifikovat' konkrétny jazykový jav. Ten je tu stvárnený najskôr $\mathrm{v}$ evidentnej opozícii $\mathrm{k}$ tomu, čo je zjavne odlišné a neskôr je akcentovaný v konkurenčnom prostredí s takým javom, ktorému je najviac podobný a od ktorého musí žiak abstrahovat', a to nielen v procese vyvodzovania termínu či zákonitosti, ale aj v konkrétnych úlohách (ako v jazykovej praxi).

Transmisivno-inštruktívny učitel' slovenčiny využíva kognitívne cvičenia v učebnici (zvyčajne zaradené pred zovšeobecnením), ale predmet pozorovania necháva $v$ statickej podobe, t. j. ako status quo. Konštruktivista riadi prácu žiakov s prameňmi poznania a opakovane navodzuje učebné situácie, ako aj metakognitívne stratégie učenia sa žiakov. V konštruktivistickom poňatí jazykového učiva je žiak postavený do pozície objavovatel'a najbližšej relevantnej zákonitosti, pričom učitel' mu pomáha vytváraním indícií. Naopak, v procese, kedy žiak rieši úlohy, učitel' s ním spolupracuje tak, že ho vedie $\mathbf{k}$ verifikácii vlastných riešení. V konečnom dôsledku tak žiak sám rozhodne, či riešenie je správne alebo nesprávne.

Konštruktivista - učitel' slovenčiny vždy pohotovo iniciuje myšlienkové operácie rôznej úrovne $v$ aktivitách žiaka. Sám upriamuje pozornost' žiakov na metakogníciu vlastných myšlienkových procesov. Rovnako sám ukazuje, ako je možné verifikovat' vlastné domnienky a vlastné konštrukty $v$ relevantnom tematickom zameraní.

\section{Algoritmus krokov v konštruktivistickom spoluobjavovaní pojmov manifestovaných ako lingvistický termín ajeho overovanie vedukačnej praxi}

Postupnost' krokov, ktoré majú viest' na hodinách slovenčiny k osvojeniu si pojmov, resp. majú byt' predovšetkým aktívnym spoznávaním ich obsahu, čo sa zavíši poznaním konkrétneho lingvistického termínu, sme sa pokúsili vyjadrit' v nasledujúcom algoritme. 


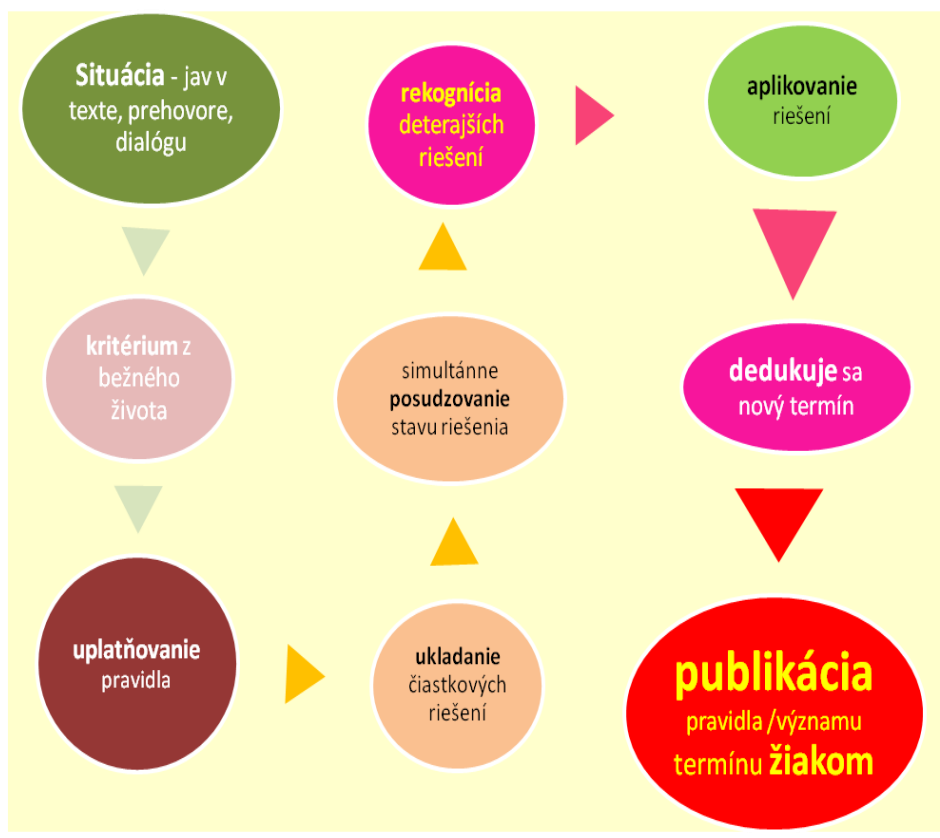

Obrázok 1 Algoritmus krokov pre dedukcii obsahu pojmu manifestovaného termínom $v$ konštruktivistickej edukácii slovenského jazyka

Celý algoritmus krokov sleduje postup od konkrétneho k abstraktnému, smeruje od elementárnej empírie s konkrétnym jazykovým javom cez abstrahovanie od iných prostriedkov s podobnou funkciou. Abstrahovanie sa opakuje, aby sa manifestoval kl'účový ukazovatel' ako konečné kritérium pre identifikáciu relevantného jazykového javu. Po skusmom a opakovanom aplikovaní kritéria žiaci/žiak dedukuje nový (učitel’om očakávaný) termín. Nakoniec sa zrekapitulujú konkrétne klúčové kroky ako skrátená či komprimovaná rekognícia celého procesu a na epizodickom princípe sa sformuluje obsah pojmu, resp. zákonitost', pričom nominácia v podobe terminologického vyjadrenia je jadrom výroku, z aspektu slovosledu je to posledný člen výroku. Nasleduje pokus o induktívne zopakovanie obsahu pojmu, čo je v skutočnosti induktívne poňatie a je totožné so sémantickým opisom pojmu/termínu. Toto zavíšenie sa môže konfrontovat' so znením pravidla/zovšeobecnenie či definíciou v učebnici. (Až do tohto momentu žiaci školskú poučku nevnímajú.) Konfrontácia má priniest' pocit úspechu a vedomie, že žiak/žiaci relevantný jav/zákonitost' objavili sami.

Učitel' vstupuje do takto projektovaného algoritmu s konkrétnou predstavou ret’azenia dedukcií, pričom sa predpokladá jeho výborná znalost' problému, aby vždy mohol reagovat' na odpovede žiakov a korigovat' ich tak, aby zodpovedali logickej algoritmickej postupnosti. V prípade mylnej dedukcie žiaci okamžite dostávajú regulujúcu indíciu, ktorá ich núti zmenit’ nesprávny výrok a nahradit' ho správnym. 
Kl'účovým pre učitel’a je strategicky projektovat' postup žiakov od známeho $\mathrm{k}$ menej známemu, pričom sa $\mathrm{v}$ maximálnej miere využíva sémantická hodnota očakávaného dedukovaného pojmu. Toto je analogické s tým, ako deti/l’udia vytvárajú svoje prvotné predpoklady - prekoncepty a ako sa to ukazuje pri tzv. naivných či jednoduchých „obrazoch sveta“. V školskom prípade ide o prekoncepty odborného či vedeckého sveta, lebo sa dedukujú termíny, ktoré tvoria databázu výrazov pre metajazyk odborníkov. Tento metajazyk však stojí nad lexikou bežného jazyka a je ňou motivovaný.

Vyššie opísané prípadové štúdie sú založené na chápaní sémantiky slova ako nástroja poznania. Jednou z najinšpiratívnejších je Gärdenforsova (2000) kognitívna sémantika. Jej abstraktný model je založený na postihnutí analogickej - mechanickej podobnosti pri tvorení pojmov, čo v prípade edukácie lingvistického učiva môžeme ilustrovat' na týchto termínoch: privlastok < privlastnit' $<$ vlastnit' $<$ vlastnost'; podobne je to v prípade abstrahovania vlastnostných prídavných mien, resp. privlastñovacích prídavných mien. Iný príklad: od chápania postavenia jednotlivca v rade či veci v istom poradí > radová č́slovka s obsahom jeden subjekt.

Takéto dedukovanie pojmov/termínov na princípe sémantickej príbuznosti bežných slov a dedukovaných pojmov je aplikovaním už spomínanej Gärdenforsovej kognitívnej sémantiky. Tento mechanický postup však musí byt' kompatibilný tiež s transpozičným tvorením slov v jazyku, musí íst' teda o istú komplementárnost' $\mathrm{k}$ Lakoffovej kognitívnej sémantike, ktorá výstižne vysvetl'uje úlohu metafory, metonymie či metaftónie ako nástrojov imaginácie v jazyku. Inými slovami: máme pojmy, ktoré sú založené na spomenutých typoch transpozície významov a pomenovaní. Uvedeným postupom pri vyvodzovaní či z aspektu kognitívnych operácií žiaka by v oblasti jazykovedy mohli byt': štýl, zámeno, častica, prístavok, aktívna veta, pasívna veta, prechodník a pod. Ako príklad konceptualizácie z oblasti syntaxe je možné považovat' metafory, ktoré formulujeme pri uvažovaní a terminologickom stvárnení problematiky o vete, na čo poukazuje L. Janovec v štúdii Věta a představová schémata (2014, s. 47 - 57).

\section{Overovanie efektívnosti deduktívneho uvažovania smerujúceho $k$ interiorizácii lingvistických pojmov založeného na princípe kognitívnej sémantiky $\mathbf{v}$ praxi}

Účinnost'/efektívnost' deduktívneho uvažovania žiaka v procese tzv. spoluobjavovania (na materiáli ,jazykového laboratória“ učitel' prináša ret’azenie indícií, aby žiaci na základe iniciovanej asociácie nachádzali správne odpovede a posúvali sa na ceste $\mathrm{k}$ správnej dedukcii pojmu/termínu, resp. zákonitosti) sme experimentálne overovali. Uvedené učivo o rozlíšení/abstrahovaní jednočlennej a dvojčlennej vety sme spracovali a realizovali edukačnú jednotku $v$ 6. ročníku ZŠs. Vytvorili sme dve skupiny žiakov: jednu, ktorá absolvovala edukačnú jednotku $\mathrm{v}$ zmysle opísanej teórie kognitívnej sémantiky a druhú, ktorá absolvovala edukačnú jednotku v postupnosti, ako ju uvádza učebnica - dôraz bol na aplikovaní oznámených poučiek/charakteristík jednočlennej a dvojčlennej vety, teda učebný obsah v štádiu osvojovania nového pojmu nebol učitel'om štruktúrovaný. 
Žiakom ako test boli predložené praktické úlohy, ktoré si vyžadovali uplatnenie nadobudnutého poznatku na konkrétnom jazykovom materiáli. V poslednom cvičení mali žiaci aj odôvodnit' svoju vol'bu (na úrovni dvojčlenná veta - jednočlenná veta), teda mali argumentovat' teoretickým vymedzením konkrétneho typu viet.

Graf č. 1 prináša porovnanie úspešnosti v obidvoch skupinách. Úspešnost' sa testovala bezprostredne na konci edukačnej jednotky na základe identických cvičení. Skupiny sme vytvorili tak, aby sme dodržali proporcionalitu zloženia z hl'adiska dosahovaných študijných výsledkov. (Nekládli sme dôraz na genderový aspekt zloženia skupín.) V grafe modrý stípec - percentuálne vyjadrenie úspešnosti žiakov - predstavuje skupinu, v ktorej sa postupovalo pri osvojovaní pojmu deduktívne, a to $\mathrm{v}$ intenciách kognitívnej sémantiky, t. j. experimentálnym spôsobom. Zelený stĺpec predstavuje percentuálne vyjadrenie úspešnosti žiakov, ktorí pracovali postupnost'ou krokov, ktoré smerujú k „hotovému“ oznámeniu, resp. opisu pojmov v podobe poučky a následne sa poučka aplikuje $\mathrm{v}$ cvičeniach. Porovnanie výsledkov ako indikátor efektívnosti postupov sme zopakovali po časovom intervale. $\mathrm{V}$ obidvoch overovaniach sme získali výsledky, ktoré hovoria v prospech deduktívneho uvažovania, vplyvom ktorého nadobúda žiak presvedčenie, že zákonitost', resp. obsah pojmu objavil sám. Na pozitívnom výsledku sa výrazne podiel'a fakt, že pri algoritme indícií a asociovaných odpovedí je zat’ažovaná epizodická pamät' žiaka. Naopak, pri oznámení pravidla či vlastností pojmu ako už hotových a uzavretých charakteristík je zatažovaná predovšetkým sémantická pamät' žiaka. Bezprostredná úspešnost' experimentálnej skupiny predstavuje $92,78 \%$, zatial' čo v kontrolnej skupine je úspešnost' $88,85 \%$. Rozdiel v miere úspešnosti je však výrazne vyšší po uplynutí časového intervalu, a to až po koniec tematického celku, čo predstavuje 4 edukačné jednotky (t. j. 2 týždne). Zatial' čo žiaci v experimentálnej skupine dosahovali úspešnost' $57,25 \%$, žiaci v kontrolnej skupine $46,11 \%$.

Nasledujúci graf vypovedá o trvácnosti nadobudnutej vedomosti - žiaci boli testovaní po uplynutí 2 týždňov, čo predstavuje 4 edukačné jednotky, ktoré však neboli orientované na tento tematický okruh, resp. boli to hodiny literárnej a slohovej výchovy.

\section{Graf 1 Porovnanie výsledkov efektívnosti zapamätávania v experimentálnej a kontrolnej skupine aj s časovým horizontom}




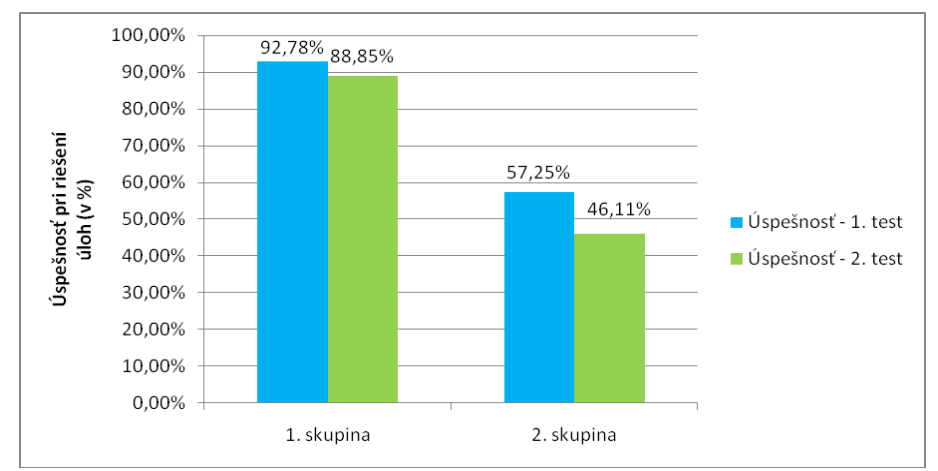

Zdroj: Vlastné spracovanie

Úspešnost' v efektívnom osvojovaní a zapamätávaní nových pojmov/termínov aplikovaním princípov kognitívnej sémantiky pripisujeme samotnému kognitívnemu procesu, ktorý je analogický postupom a stratégiám $\mathrm{v}$ aktoch nominácie $\mathrm{v}$ prirodzenom jazyku (t. j. v procesoch primárneho pomenovávania entít a súčastí sveta tak $\mathrm{z}$ ontologického, ako aj fylogenetického aspektu). Slovo, ktoré je v jazyku už etablované a jeho význam je známy, dáva svojou sémanticko-formálnou štruktúrou základ pre vznik nového pojmu manifestovaného odborným termínom. V prípade osvojovania pojmu $\mathrm{v}$ edukácii ide o reverzný proces, teda o modelovanie prirodzeného procesu zrodu termínu z bežného pomenovania, resp. procesu (a jeho pomenovania), ktorý k zrodu termínu viedol. Osobitosti nadobúda nami aplikovaný poznávací algoritmus postupnosti $\mathrm{v}$ radení indícií a následných (žiackych) asociácií vplyvom toho, či očakávaný termín/pojem vznikol ako výsledok jednoduchej alebo opisnosti, alebo metafory, resp. metonymie, alebo obidvoch súčasne vzhl’adom na východiskovú lexému spravidla bežné pomenovanie, resp. združené pomenovanie. Spomenutú osobitost' musí učitel' ako architekt diskurzívneho priestoru a následnej kognitívnej aktivity žiaka zohl'adnit' v základnom projektovaní algoritmického procesu.

Ďalšia miera efektívnosti uvedeného učiva by sa relevantne dala posúdit' podl'a individuálne tvorenými mentálnymi mapami žiakmi obidvoch skupín. Metodologicky by bolo relevantné vychádzat' zo štúdie J. Duchovicovej a D. Gunisovej (2017, s. 81 - 94), pričom zdôrazňujeme individuálne vytváranie mentálnej mapy, resp. jej zdokonal'ovanie a „zahust'ovanie“ pojmov a vzt'ahov po d'alších edukačných aktivitách. Predpokladáme, že v mentálnom mapovaní by boli úspešnejší žiaci, ktorých učebný obsah bol štruktúrovaný, prešiel procesom aktívneho poznávania a dedukovania spojeného so zážitkom, teda primárne bola aktivovaná ich epizodická pamät' a až následne sa poznatky ,preorganizovali“ a uložili ako produkt sémantickej pamäte.

\section{Záver}

V procese konštruktivisticky poňatého vyučovania sa preferuje epizodická pamät' pred sémantickou, to znamená, že proces zavádzania pojmu sa po ret’azení dedukcií založených na opakovaných analýzach a syntézach 
rekapituluje a zavedie sa pojem/termín, nie opačne. Zovšeobecnenie v učebnici, ktoré je známe ako tzv. poučka by malo byt' konštruované, t. j. malo by sa v konečnej formulácii zákonitosti postupovat' od jednotlivostí k zovšeobecneniu, nie naopak. Súčasná prax však ponúka opak, zovšeobecnenia majú tzv. tvrdý začiatok, teda pojem je konštruovaný sémanticky. (Rovnako to platí aj pre kompozíciu textov v učebniciach rôznych predmetov, najmä však tých textov, ktoré sú zdrojom poznania a sú určené na improvizáciu realizovanú žiakom, a to ako prejav jeho najvyššej miery porozumenia zdroju poznania - textu.).

Poznanie je vektorová veličina: smeruje odniekial' niekam. A to od známeho k neznámemu. Teda už v samotnom poznaní je implicitne obsiahnutá epizóda, čím sa k celej problematike pripisuje časový faktor následnosti $\mathrm{v}$ prirodzenom plynutí času od minulého k prítomnému. $\mathrm{V}$ tomto zmysle nami preferovaný model konceptualizácie a využívanie konceptov či prekonceptov implicitne obsahuje postupnost' od skoršieho k neskoršiemu, a teda aj od menej známeho k známejšiemu, od konkrétneho k abstraktnému, od jednotlivého k všeobecnému. Ukazuje sa, že všetky tu vymenované požiadavky sú vlastne funkciou sémantickej dedukcie a účinkujú nie ako jednotlivé kognitívne operácie, ale ako jeden celok, teda koncept, pričom sa vychádza z už osvojených konceptov, ktoré sú vo vzt’ahu k aktuálne konceptualizovanému pojmu a tento vzt'ah je identický ako je vzt'ah prekonceptu a konceptu. Vzájomná súvislost' s už nadobudnutou vedomost'ou $\mathrm{v}$ didaktickom kontexte dostala pomenovanie inferencia. Bez zjavných inferencií nie je možné prehlbovat' už nadobudnuté vedomosti z oblasti jazykovedy, pretože medzi nimi je kauzalita a logická súvislost'. V konečnom dôsledku to znamená aj predpoklad kohézie sémantickej siete $\mathrm{v}$ mentálnom priestore subjektu. Nemenej dôležitý je fakt, že na aktivizovaní konkrétnych prienikov či uzlov v sémantickej sieti je asociácia. V dôsledku toho hovoríme o asociačno-sémantickej sieti, ktorej zahustenie v konečnom dôsledku rozhoduje o tom, ako rýchlo a ako l'ahko si osvojujeme nové pojmy.

V školskej praxi sa očakáva, že žiak si postupne osvojí celý komplex pojmov/termínov, ktoré bude funkčne používat'. Termíny sa podobne ako koncepty hierarchizujú. $Z$ toho vyplývajú dôsledky pre úspešnost' jednotlivca pri d’alšom osvojovaní si nových pojmov, a teda pri individuálnom napredovaní. Nezanedbatel'nou súčastou toho je trvalé uloženie pojmu/termínu. Túto stránku problematiky sme sledovali v experimentálnej edukačnej jednotke. Percentuálne vyhodnotenie úspešnosti či efektívnosti osvojovania si pojmov bezprostredne, ale aj po časovom intervale (rovnakom pre obidve skupiny) jednoznačne vypovedá o progresívnosti konštruktívne projektovaného učenia založeného na vytváraní konceptuálnych priestorov a „uzemneného“v prekonceptoch či miskonceptoch žiaka.

Prípadové štúdie, ktoré sme v texte uviedli, sú príkladom toho, ako na jednej strane štruktúrovat' učebný obsah a spájat' ho s vnímaním zážitku dvojakého druhu, a to na jednej strane zážitku sprostredkovaného slovesným umením (a $\mathrm{z}$ toho istého slovesného priestoru prijat' do diskurzívneho priestoru edukácie relevantný jazykový materiál s akcentovaním očakávaného jazykového javu) a na druhej strane zážitku plynúceho z poznania, že zákonitost’ či obsah žiak objavil sám. Na druhej strane sú prípadové štúdie naplnením poznania, ktoré 
Aristoteles (1975, s. 128) v súvislosti s porozumením skúmaného charakterizoval takto: „Předne je třeba zkoumat, zda zrčení (t. j. definice) bylo vytvořeno $\mathrm{z}$ toho, co je dřívější a známější. Určení se totiž udává proto, aby se poznalo to, o čem je řeč (...) Nepoznávame však z kdečeho, nýbrž z toho, co je dřívější a známější (...). A tak je zřejmé, že kdo nevytvořil určení takovými prostředky, určení ve skutečnosti ani neudal“.

Učenie sa novým konceptom - významom - je sprevádzané zväčšovaním konceptuálnych priestorov na základe pridávania nových osí kvality alebo pribúdaním celých nových konceptuálnych priestorov. Gärdenfors (in Benuskova, 2005, s. 241) považuje pridanie novej osi kvality za ekvivalentné vedeckému objavu. Zavedenie nových konceptuálnych priestorov do kognície jedinca je proces analogický so zavádzaním nových dimenzií a konceptuálnych priestorov počas kognitívneho vývinu diet’at’a. Primárnou aktivitou je príst' s novými dimenziami na vysvetlenie vecí. Abstraktné koncepty sú novými dimenziami Mali by vznikat' hierarchicky na báze už existujúcich konceptov a dimenzií.

Štúdia súvisí s riešením projektu Prax v centre odborovej didaktiky, odborová didaktika v centre praktickej prípravy / APVV-15-0368.

Táto práca bola podporovaná agentúrou na podporu výskumu a vývoja na základe zmluvy č. APVV-15-0368.

\section{Bibliographic references}

ALEFIRENKO, N. F. 2009. Zivoje slovo. Problemy funkcionalnoj lexikologii. Moskva: Nauka, 342 s. ISBN 978-5-02-037174-3.

ALEFIRENKO, N. F. - K ORINA, N. B. 2011. Problemy kognitivnoj lingvistiki. Nitra: FF UKF v Nitre, 216 s. ISBN 978-80-8094-987-7.

ARISTOTELES. 1975. Organon 5, Topiky. Praha: Nakladatelstvi CSAV 1975.

BENUSKOVA, L. 2005. Kde sa jazyk stretava s vedomim. In: Jazyk a kognicia. Ed. J. Rybar, V. Kvasnicka, I. Farkas. Bratislava: Kalligram, s. 235 - 261. ISBN 80-01-02079-7.

DUCHOVICOVA, J. - GUNISOVA, D. 2015. Subjektivny pohlad ziaka na sposob strukturovania

uciva ucitelom. In: Lifelong Learning - celozivotni vzdelavani, roc. 5, c. 2, s. 148-171. ISSN 1804-526X.

DUCHOVICOVA, J. - KOZAROVA, N. 2017. Mental representation of learning content and learning style. In: Slavonic Pedagogical Studies Journal, Volume 6 Issue 1, s. 81 - 94. ISSN 1339 - 8660.

GARDENFORS, P. 2000. Conceptual Spaces. The geometry of Thought. The MIT Press.

JANOVEC, L.2014. Veta a predstavova schemata. In: Obraz cloveka v jazyku. Zbornik prispevkov z medzinarodnej vedeckej konferencie. Ed. J Vanko. Nitra: FF UKF, s. 47 - 57. ISBN 978-80-558-0560-3.

KABATOVA, M. 2005. Od ACT-R k tvorbe kognitivneho tutora. In: Jazyk a kognicia. Ed. J. Rybar, V. Kvasnicka, I. Farkas. Bratislava: Kalligram 2005, s. 167 - 186. ISBN 80-01-02079-7. 
LAKOFF, G. 2002. Zeny, ohen a nebezpecne veci. Brno: Host,. 282 s. (Metaphors We Live By. Chicago - London 1980). ISBN 80-86138-78-X.

MANAK, J. - JANIK, T. - SVEC, V. 2008. Kurikulum v soucasne skole. Brno: Paido. 127 s. ISBN 978-80-7315-175-1.

MARES, J. 2001. Stukturovani uciva, vyucovaci a ucebni strategie. In: Cap, J., Mares, J. Psychologie pro ucitele. Praha: Portal, s. 441-472. ISBN 807178-463-X.

MARES, J. 2011. Uceni a subjektivni mapy pojmu. Pedagogika, roc. 61, c. 3, s. $215-247$,

ISSN 1338-0982.

MARKHAM, K. M. - MINTZES, J. J. - JONES, M. G. 1994. The Concept Maps as a Research and Evaluation Tool: Further Evidence of Validity. Journal of Research in Science Teaching, vol. 31, no. 1, pp. 91-101, ISSN 0022-4308.

SLAVIK, J. - SMEJKALOVA, M. 2016. K pojeti didaktiky ceskeho jazyka jako vedecke discipliny. s. $113-122)$. In: Studie z aplikovane lingvistiky. Cislo 1, rocnik 7, s. $111-120$. ISSN 1804-3240.

SEBESTA, K. 2016. Aplikovana lingvistika vs. lingvistika v aplikaci aneb S kym/cim se vlastne polemizuje? In: Studie z aplikovane lingvistiky. Cislo 1, rocnik 7, s. 121 - 130. ISSN 1804-3240.

SEFRANEK, J. 2005. Vyznamy neexistuju. In: Rybar, J. - Kvasnicka, V. Farkas, I. In: Jazyk a kognicia. Bratislava. Kaligram, s. 145 - 187. ISBN 8001-02079-7.

STEPANIK, S. 2011. Konstruktivisticke paradigma ve vyucovani ceskemu jazyku. In: Didakticke studie roc. 3. c. 2, s. 73 - 78. ISSN 1804-1221

SKODA, J. - DOULIK, P. 2011. Psychodidaktika. Metody efektivniho a smysluplneho uceni a vyucovani. Praha: Grada, 2011. 208 s. ISBN 978-80247-3341-8.

WIERZBICKA, A. 2014. Semantika: elementarni a univerzalni semanticke jednotky. Praha: Univerzita Karlova v Praze, 549 s. ISBN 978-80-246-22897.

doc. PhDr. Zuzana Kováčová, PhD.

Department of Slovak Language and Literature

Constantine the Philosopher University in Nitra

Štefánikova 67 ,

94974 Nitra

Slovakia

zkovacova@ukf.sk 